\title{
Experimental Studies on Hydrothermal Treatment of Municipal Solid Waste for Solid Fuel Production
}

\author{
Djaenudin ${ }^{1 *}$, Dani Permana', Mahyar Ependi², Herlian Eriska Putra ${ }^{1}$ \\ Research Unit for Clean Technology, Indonesian Institute of Sciences, Jl. Cisitu Sangkuriang No. 21 D Bandung \\ 40135, Indonesia \\ 2 Bureau of General Affairs, Indonesian Institute of Sciences, J. Cisitu Sangkuriang No. 21 D Bandung 40135, \\ Indonesia \\ * Corresponding author's e-mail: djae004@lipi.go.id
}

\begin{abstract}
Using the Hydrothermal process to reduce the volume of the Municipal Solid Waste (MSW) which is mostly organic component and to utilize the solid powder resulted as coal-like solid fuel will contribute not only to solving the MSW problem but also reducing the coal consumption in the power plant. In this study, the hydrothermal processes were conducted using a laboratory scale apparatus with MSW components as the samples. The process parameters comprised temperature, solid load, and holding time. Four components were used as representative of organics and plastics in the municipal solid waste. In this study, the experiments were done performed at various temperatures, $180^{\circ} \mathrm{C}, 200^{\circ} \mathrm{C}$, and $220^{\circ} \mathrm{C}$ inside an experimental autoclave. The results of the experiments show that the process time, the water amount and the temperature which are used in hydrothermal process, affect the proximate and ultimate compositions. The moisture and fixed carbon content decrease and the volatile matter increases, so that the calorific value of MSW increases. On the basis of the experiments, the optimum hydrothermal process parameters are feed to water ratio of $1 / 1(250 \mathrm{~g} / 250 \mathrm{ml})$, temperature of $180^{\circ} \mathrm{C}$, and holding time of 90 min. It also can be concluded that the hydrothermal process can be applied to MSW to produce solid fuel.
\end{abstract}

Keywords: holding time, hydrochar; hydrothermal treatment; municipal solid wastes; feed to water ratio.

\section{INTRODUCTION}

In recent years, the energy consumption has increased rapidly. BP reported that the increasing of energy consumption in Indonesia has elevated in the past decade [BP, 2017]. The energy consumption puts demand on energy resources that makes them scarcer. Fossil fuels, such as oil, coal, and natural gas, are still main choice in Indonesia. Thus, the efforts to change the consumption of fossil fuel to the renewable energy are made in Indonesia. Unfortunately, the problems faced are not only the energy sector, but also environmental problems, especially municipal solid waste (MSW) disposal.

Mostly in developing countries, the present practice of MSW disposal is open dumping and landfills which creates environmental, land limitation and social problems. In addition, the unsanitary and unstable landfills have a negative impact on the environment [Assmuth, 1992; Lander et al., 2009] and threaten human health [Durmusoglu et al., 2010; Hung et al., 2009]. The traditional incineration is faced with the problems of pollution as well as the public opposition. Thermal processes such as combustion, pyrolysis, and gasification offer great benefits over the traditional methods of MSW disposal. These thermal methods not only recover useful energy values from MSW but also reduce the quantity of waste being ultimately sent to the landfill. Many countries started to encourage the conversion of waste to alternative energy.

The characteristics of MSW are different in each country. It is strongly influenced by the size of population, living style, culture, seasons, and even regulation on MSW disposal. In the majority of developing countries, the composition of MSW is 
dominated by organics such as biomass, food residues, and plastics which could be useful resources for energy recovery. However, the main obstacle is the moisture content of MSW that makes it difficult to recover energy by thermal processes [Liang et al., 2008]. One of the thermal processes that can be operated in the wet condition is hydrothermal treatment (HT). HT is employed for producing a coallike solid fuel called hydrochar, [Funke and Ziegler, 2010; Libra et al., 2011; Ramke et al., 2009]. Studies are conducted about hydrothermal treatment to produce useful organic matter or to recover energy from organic wastes, sludge, real biomass, and industrial waste [Jooma et al., 2003; Shanableh et al., 2000; He et al., 2008; Goto et al., 2004]; however, only few are designed to produce solid fuel. In this present study, the authors investigated the effect of hydrothermal process with various conditions of temperature, holding time, and water amount (ratio feed to water); which were applied to MSW components as the sample to produce solid fuel. The proximate, ultimate, and calorific value analyses of samples were also conducted. The results were then analyzed to obtain the optimum process parameters.

\section{EXPERIMENTAL}

\section{The materials}

The percentage of organic and plastic in Bandung city, Indonesia could be seen in Figure 1. According to the data, the weight percentage of organic and plastic is $45.36 \%$ and $4.64 \%$ respectively. In this research, a mixture of MSW components was represented by banana skin, water hyacinth and plastics such as styrofoam and polypropylene, which were tested as the sample (Fig. 2). It consists of $22.68 \%$ banana skin, $22.68 \%$ water hyacinth, $2.32 \%$ styrofoam, and $2.32 \%$ polypropylne. The samples were manually prepared by blending them after being cut into small sizes.

\section{Experimental apparatus and procedure}

The experiments of the hydrothermal process were carried out in a $1 \mathrm{~L}$ laboratory scale high pressure reactor. The reactor can be operated at a maximum pressure of $50 \mathrm{MPa}$. The reactor was heated by an electrical heater. The temperature was controlled at $\pm 2^{\circ} \mathrm{C}$. For the test, $250 \mathrm{~g}$ of sample and a certain amount of distilled water were placed inside the reactor, as shown in Figure 3.

The amount of water used in the experiment was $250 \mathrm{ml}$ and $500 \mathrm{ml}$ (ratio feed to water 1:1 and 1:2). Before the experiment, nitrogen gas was released into the reactor in order to create an oxygen free condition inside the autoclave. Then, the experimental setup was heated. The experiments were performed for the autoclave temperature of 180,200 , and $220^{\circ} \mathrm{C}$. The holding times were varied from 30, 60 and $90 \mathrm{~min}$. Those three main processing parameters, i.e., (1) the ratio feed to water, (2) the temperature, and (3) the holding times, were varied as shown in Table 1.

In order to ensure uniformity of samples, the stirrer was kept mixing along the process. After the process was completed, the heater was turned off and the release valve was opened slowly to release steam inside the reactor. The pressure inside the

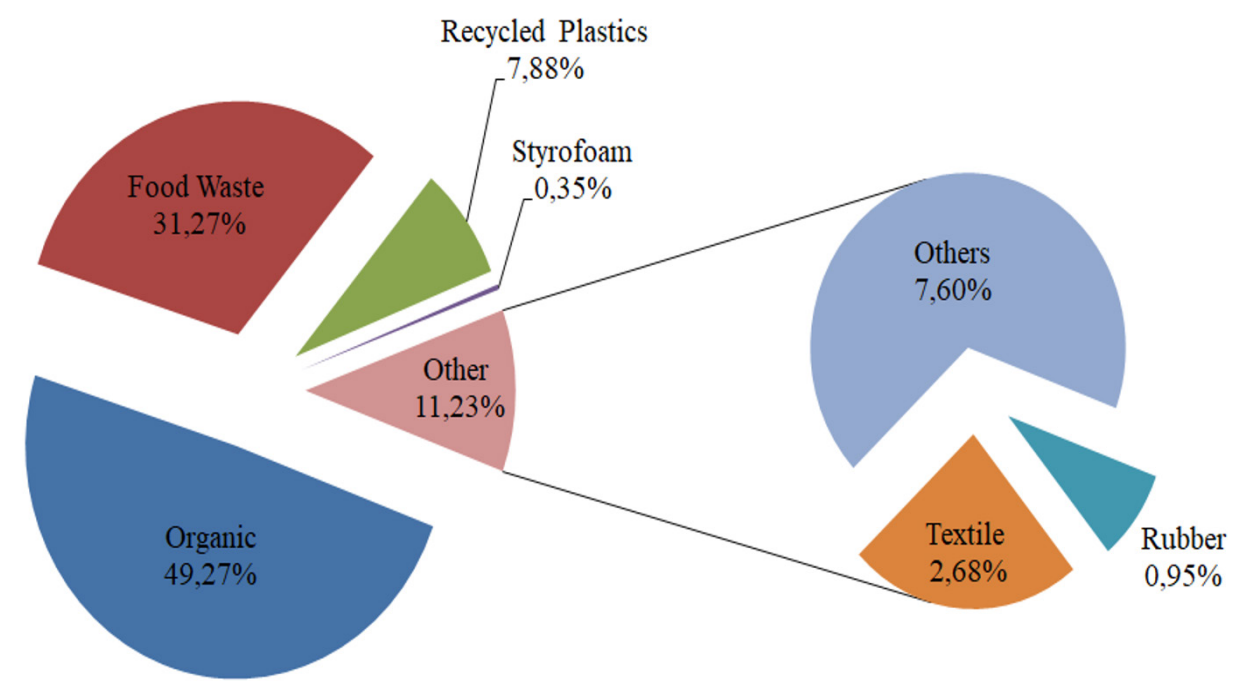

Figure 1. The composition of MSW in the city of Bandung 


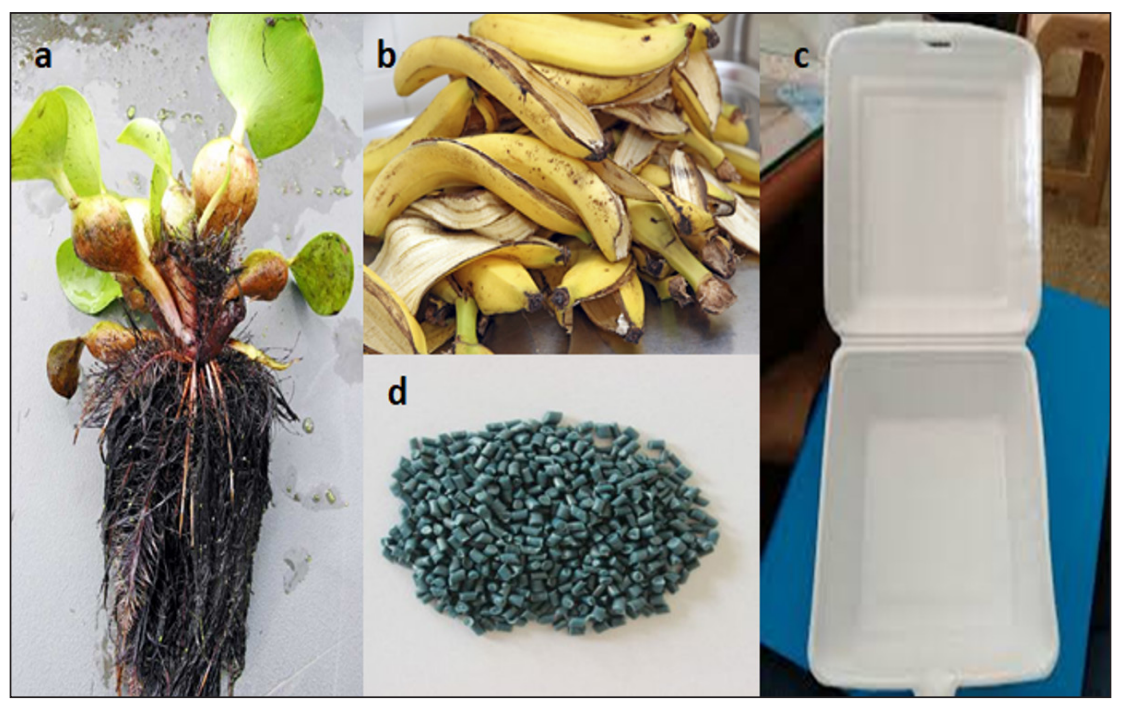

Figure 2. Components of MSW: a) water hyacinth, b) banana skin, c) styrofoam, d) polypropylene

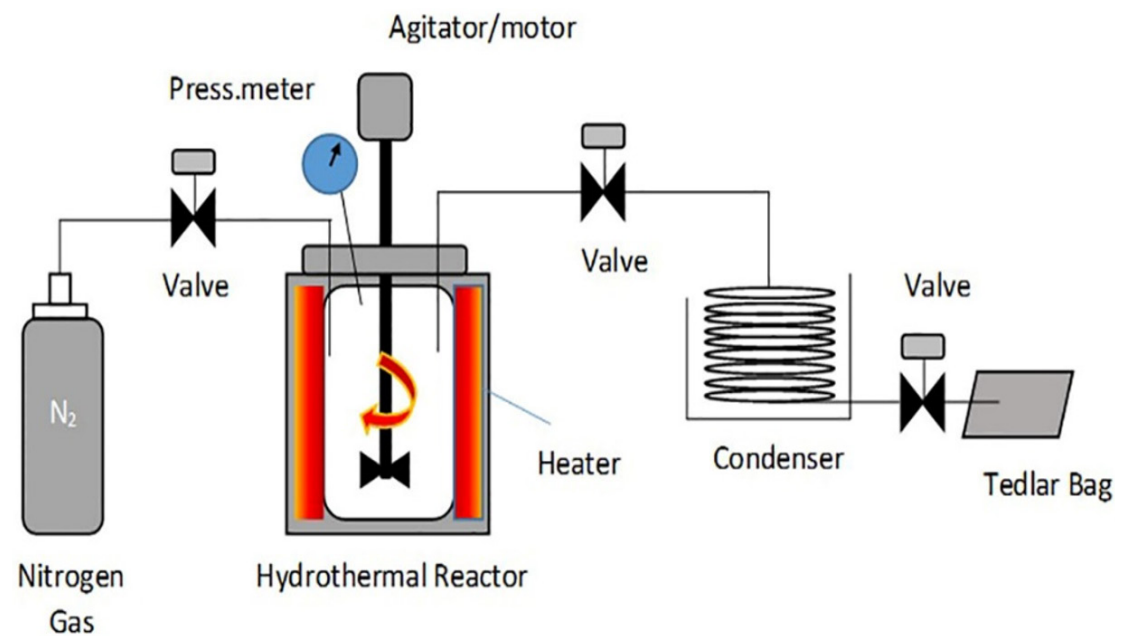

Figure 3. Schematic diagram of experimental setup

reactor reduced quickly, but the temperature of the reactor was still high. The products were taken out of the reactor after the room temperature reached. The schematic diagram of experimental setup is shown in Figure 2. All processed samples were then dried in a constant-temperature oven at $110^{\circ} \mathrm{C}$ for 24 hours and crushed to powder for analysis.

\section{Sample preparation}

Four components of MSW were tested in this research. They are polypropylene, styrofoam, banana skin, and water hyacinth. The dried samples were analyzed at TekMIRA to find their properties, as shown in Tables 3 and 4. All dried original components

Table 1. Variation of experimental operating conditions

\begin{tabular}{|l|c|c|c|c|c|c|c|c|c|}
\hline Exp. ID & $\mathrm{A} 11$ & $\mathrm{~A} 12$ & $\mathrm{~A} 13$ & $\mathrm{~A} 21$ & $\mathrm{~A} 22$ & $\mathrm{~A} 23$ & $\mathrm{~A} 31$ & $\mathrm{~A} 32$ & A33 \\
\hline $\mathrm{T}\left({ }^{\circ} \mathrm{C}\right)$ & 180 & 180 & 180 & 200 & 200 & 200 & 220 & 220 & 220 \\
\hline $\mathrm{HT}(\mathrm{min})$ & 30 & 60 & 90 & 30 & 60 & 90 & 30 & 60 & 90 \\
\hline $\mathrm{FWR}(\mathrm{ml})$ & $1 / 1$ & $1 / 1$ & $1 / 1$ & $1 / 1$ & $1 / 1$ & $1 / 1$ & $1 / 1$ & $1 / 1$ & $1 / 1$ \\
\hline Exp. ID & $\mathrm{B} 11$ & $\mathrm{~B} 12$ & $\mathrm{~B} 13$ & $\mathrm{~B} 21$ & $\mathrm{~B} 22$ & $\mathrm{~B} 23$ & $\mathrm{~B} 31$ & $\mathrm{~B} 32$ & $\mathrm{~B} 33$ \\
\hline $\mathrm{T}\left({ }^{\circ} \mathrm{C}\right)$ & 180 & 180 & 180 & 200 & 200 & 200 & 220 & 220 & 220 \\
\hline $\mathrm{HT}(\mathrm{min})$ & 30 & 60 & 90 & 30 & 60 & 90 & 30 & 60 & 90 \\
\hline FWR $(\mathrm{ml})$ & $1 / 2$ & $1 / 2$ & $1 / 2$ & $1 / 2$ & $1 / 2$ & $1 / 2$ & $1 / 2$ & $1 / 2$ & $1 / 2$ \\
\hline
\end{tabular}

Exp - Experimental, FWR - Feed to Water Ratio 
Table 2. Standards used for the testing at TekMIRA

\begin{tabular}{|l|c|}
\hline \multicolumn{1}{|c|}{ Parameter } & Standard Method \\
\hline Moisture & ISO 11722 ASTM D.3173 \\
\hline Ash & ISO 1171 ASTM D.3174 \\
\hline Volatile matter (VM) & ISO 562 \\
\hline Fixed carbon (FC) & $100 \%-M-A s h-V M$ \\
\hline Carbon (C) & ISO 625 ASTM D.3178 \\
\hline Hydrogen (H) & ISO 625 ASTM D.3178 \\
\hline Nitrogen (N) & ISO 332 ASTM D.3179 \\
\hline Sulfur (S) & ASTM D.4239 \\
\hline Oxygen (O) & $100 \%-C-H-N-S-A s h$ \\
\hline Calorific value & ASTM D.5865 \\
\hline
\end{tabular}

were analyzed in air dried base (adb). The standards used for the testing are shown in Table 2.

Dried processed samples were tested in TekMIRA for calorific value analysis. The $\mathrm{C}, \mathrm{H}$, and $\mathrm{N}$ contents were measured with an elemental analyzer (Perkin Elmer 2400 Series II CHN). S was not detected during analyzing. $\mathrm{O}$ was determined by mass balance $(\mathrm{O}=100 \%-\mathrm{C}-\mathrm{H}-\mathrm{N}-\mathrm{Ash})$. The proximate, ultimate, and calorific value analyses of each original component are presented in Table 3. The properties of plastic and organic components are quite different. Moisture, fixed carbon, and ash content of plastics are much lower compared to the organics. Further, the volatile content of plastics is very high, which is the key element to initiate ignition. However, organics contain high oxygen, due to the content of cellulose, hemicellulose and lignin in the organic, compared to plastics. The calorific value of plastics is much higher compared to organics. On the other hand, Table 3 shows that the sample which has of high volatile matter content can provide a high calorific value.

\section{RESULTS AND DISCUSSIONS}

In this experiment, crushed dried samples after hydrothermal process were analyzed for proximate, ultimate, and calorific value. All dried processed samples were tested in air dried base (adb). The results of proximate and calorific value analyses can be seen in Table 4 and ultimate analysis can be seen in Table 5 .

\section{Proximate Analysis}

The proximate analysis was the most general method used to determine the quality of solid fuels. It comprises an analysis of fixed carbon (FC), volatile matter (VM) and ash content (Ash). FC was the ignitable residue once the volatile matter was completely burned.

It can be seen that the moisture content decreases significantly. The moisture content ranges from 1.41 to $0.14 \%$ so that the hydrothermal process can reduce the moisture content from 80.22 to $98.22 \%$ compared with moisture content in dried mixed component. This is because of the degradation of pore systems in substances by heat. Significant decrease of the moisture content leads to an increase of combustible elements such as volatile matter and fixed carbon. The influence of process water, holding time and process temperature is unclear in this result.

Table 4 also explains the variation of the ash content in mixed component after hydrothermal process. It can be seen that ash content increases partially. Under the conditions of feed to water ratio $1 / 1$, process temperature of $180^{\circ} \mathrm{C}$ and holding time of 90 minutes, the moisture content in

Table 3. Original component analyses

\begin{tabular}{|c|c|c|c|c|}
\hline Analysis & Polypropylene & Styrofoam & Banana Skin & Water Hyacinth \\
\hline \multicolumn{5}{|c|}{ Proximate $^{\text {adb }}$} \\
\hline Moisture & 0.04 & 0.11 & 3.31 & 12.3 \\
\hline Ash (\%) & - & 0.36 & 8.97 & 8.26 \\
\hline VM (\%) & 99.7 & 99.1 & 68.4 & 63.9 \\
\hline $\mathrm{FC}(\%)$ & 0.16 & 0.39 & 19.2 & 15.3 \\
\hline \multicolumn{5}{|c|}{ Ultimate $^{\text {adb }}$} \\
\hline Carbon & 77.6 & 85.7 & 51.5 & 40.08 \\
\hline Hydrogen & 10.47 & 5.68 & 6.2 & 5.28 \\
\hline Nitrogen & 0.12 & 0.16 & 1.82 & 3.79 \\
\hline Sulfur & - & - & 0.17 & - \\
\hline Oxygen & 11.81 & 8.1 & 31.3 & 50.85 \\
\hline HHV & 45.44 & 39.3 & 20.9 & 14.9 \\
\hline
\end{tabular}

$\mathrm{adb}$ - air dry basis 
Table 4. Proximate and calorific value analyses of mixed component after HP

\begin{tabular}{|c|c|c|c|c|c|}
\hline \multirow{2}{*}{$\begin{array}{c}\text { Feed to } \\
\text { Water Ratio }\end{array}$} & \multirow{2}{*}{$\begin{array}{l}\text { Process } \\
\text { Condition }\end{array}$} & \multicolumn{4}{|c|}{ Proximate analysis (adb) } \\
\hline & & MC & Ash & VM & FC \\
\hline $\mathrm{g} / \mathrm{ml}$ & ${ }^{\circ} \mathrm{C} \_\min$ & $\%$ & $\%$ & $\%$ & $\%$ \\
\hline \multirow{9}{*}{$1 / 1$} & 180_30 & 0.72 & 10.48 & 83.75 & 5.05 \\
\hline & $180 \_60$ & 0.86 & 11.46 & 81.40 & 6.28 \\
\hline & 180_90 & 1.41 & 7.09 & 89.32 & 2.18 \\
\hline & 200_30 & 1.30 & 10.71 & 83.23 & 4.76 \\
\hline & 200_60 & 0.42 & 7.79 & 87.21 & 4.58 \\
\hline & 200_90 & 0.75 & 9.29 & 83.86 & 6.10 \\
\hline & 220_30 & 0.74 & 11.40 & 82.27 & 5.59 \\
\hline & 220_60 & 0.72 & 10.94 & 81.10 & 7.24 \\
\hline & 220_90 & 0.14 & 8.24 & 89.73 & 1.89 \\
\hline \multirow{9}{*}{$1 / 2$} & 180_30 & 0.68 & 7.57 & 89.05 & 2.71 \\
\hline & $180 \_60$ & 1.25 & 8.98 & 86.88 & 2.89 \\
\hline & 180_90 & 0.37 & 8.25 & 87.18 & 4.20 \\
\hline & 200_30 & 1.04 & 10.36 & 85.14 & 3.46 \\
\hline & $200 \_60$ & 0.40 & 10.68 & 84.07 & 4.85 \\
\hline & 200_90 & 1.41 & 10.29 & 84.40 & 3.90 \\
\hline & 220_30 & 0.54 & 11.29 & 83.75 & 4.42 \\
\hline & 220_60 & 0.78 & 8.70 & 88.87 & 1.65 \\
\hline & 220_90 & 0.48 & 9.32 & 86.74 & 3.46 \\
\hline
\end{tabular}

mixed component after process is the lowest so that it has the highest content of combustible elements. Moreover, in holding time of 30 minutes, it can be seen that ash content is more for higher process temperature used and less process water used. The characteristics of ash performance a main role to upscale system design. Ash, inorganic residue left over after burning process, can cause slagging, fouling, and corrosion of reactor if not handled carefully [Putra et al., 2020].

The variation of the volatile matter content in the mixed component after the hydrothermal process is shown in 6 . It can be seen that the volatile matter content increases significantly. This volatile matter content gain was mainly caused by the hydrolysis and the carbonization of the organic component. The volatile matter content in the samples ranged from 81.10 to $89.73 \%$ so that the hydrothermal process can increase the volatile matter content from 17.02 to $29.48 \%$ compared to the predicted volatile matter content in dried mixed component. Increasing of ash and volatile matter content will contribute to a decrease in the fixed carbon content. It can be seen that under the conditions of feed to water ratio $1 / 1$, process temperature of $180^{\circ} \mathrm{C}$, and holding time of 90 minutes, the processed sample has the lowest ash content, and very high volatile matter content. It can be concluded that this condition is favorable for obtaining higher calorific value, although the influence of process water and holding time is unclear in this result. In general, the lower the amount of process water used in process, the lower volatile matter content in the sample, since a decrease in the biomass to water ratio reduces the possibility interaction between the sample and reaction medium.

The variation of fixed carbon content in mixed component after hydrothermal process. It can be seen that the fixed carbon content in the processed samples decreases significantly. Evidently, the measured fixed carbon content in processed sample ranged from 7.24 to $1.65 \%$ and the predicted fixed carbon content in dried mixed component was $15.74 \%$. The fixed carbon loss leads to an increase in the volatile matter content.

\section{Ultimate Analysis}

Ultimate analysis is used to determine the chemical compositions of the sample. The variation of carbon and hydrogen content in the processed sample are shown in Table $5 \mathrm{~s}$. It can be seen that carbon and hydrogen content in mixed component after the hydrothermal process increased significantly. This increase was mainly caused by carbonization and hydrolysis in the process. The carbon content in the processed sample ranged from 65.15 to $72.93 \%$ so that the hydrothermal process increased the carbon content from 32.85 to $48.71 \%$ compared to the predicted carbon content in dried mixed component. In addition, it can be seen that the carbon content is higher for longer holding time operated or higher process temperature used.

The hydrogen content in the processed sample ranged from 6.87 to $9.94 \%$ so that the hydrothermal process increased hydrogen content from 10.62 to $60.06 \%$ compared to the predicted hydrogen content in dried mixed component. Increasing the carbon and hydrogen contents will lead to decreases in the nitrogen and oxygen contents. The variation of the nitrogen and oxygen contents in processed sample is shown in Figures 4.33 and 4.34 , respectively. It can be seen that the nitrogen and oxygen contents decrease after the process. Decreases of the oxygen and nitrogen contents in the sample will reduce the formation of $\mathrm{NO}_{\mathrm{x}}$ emission at low combustion temperature [ $\mathrm{Ji}$ et al., 2020]. Thus, burning the processed sample is 
Table 5. Ultimate analysis of mixed component after HP

\begin{tabular}{|c|c|c|c|c|c|}
\hline \multirow{2}{*}{$\begin{array}{l}\text { Ratio of sample } \\
\text { to water }\end{array}$} & \multirow{2}{*}{ T_HT } & \multicolumn{4}{|c|}{ Ultimate analysis (adb) } \\
\hline & & C & $\mathrm{H}$ & $\mathrm{N}$ & 0 \\
\hline $\mathrm{g} / \mathrm{ml}$ & ${ }^{\circ} \mathrm{C} \_$min & $\%$ & $\%$ & $\%$ & $\%$ \\
\hline \multirow{9}{*}{$1 / 1$} & 180_30 & 65.15 & 6.87 & 1.63 & 15.87 \\
\hline & $180 \_60$ & 69.87 & 8.84 & 1.38 & 8.45 \\
\hline & 180_90 & 71.38 & 8.01 & 1.12 & 12.40 \\
\hline & 200_30 & 66.34 & 6.98 & 1.91 & 14.06 \\
\hline & 200_60 & 72.93 & 8.83 & 1.12 & 9.33 \\
\hline & 200_90 & 70.37 & 9.94 & 1.36 & 9.04 \\
\hline & 220_30 & 71.89 & 8.50 & 1.43 & 6.78 \\
\hline & $220 \_60$ & 70.70 & 7.66 & 1.41 & 9.29 \\
\hline & 220_90 & 71.14 & 7.00 & 1.29 & 12.33 \\
\hline \multirow{9}{*}{$1 / 2$} & 180_30 & 69.27 & 7.81 & 1.14 & 14.21 \\
\hline & $180 \_60$ & 67.86 & 7.05 & 1.27 & 14.84 \\
\hline & 180_90 & 68.73 & 7.24 & 1.53 & 14.25 \\
\hline & 200_30 & 67.08 & 7.24 & 1.66 & 13.66 \\
\hline & $200 \_60$ & 67.39 & 7.63 & 1.71 & 12.59 \\
\hline & 200_90 & 69.39 & 8.40 & 1.45 & 10.47 \\
\hline & 220_30 & 68.10 & 7.12 & 1.59 & 11.90 \\
\hline & 220_60 & 70.39 & 7.33 & 0.93 & 12.65 \\
\hline & 220_90 & 69.93 & 7.58 & 1.33 & 11.84 \\
\hline
\end{tabular}

good for environment. The nitrogen content in the processed sample ranged from 0.93 to $1.92 \%$.

After the process, the oxygen content in the sample decreases significantly. Evidently, the oxygen content in the processed sample ranged from 15.87 to $6.78 \%$ so that hydrothermal process can decrease the oxygen content from 113.35 to $399.41 \%$, compared to the predicted oxygen content in dried mixed component. Such decrease leads to increase in the carbon and hydrogen contents. Besides, the oxygen content in the process sample was still higher compared to coal. This is significant because the more oxygen a fuel contains, the easier it is to start burning or achieve its ignition. On the basis of the trend, using less process water will result in lower oxygen content of the processed sample.

\section{Higher Heating Value}

The higher heating value (HHV) of a sample is influenced by its composition or element. It is important to compare the calorific value of the samples before and after the HT process. Figure 4 shows the variation of calorific value after the hydrothermal process. It can be seen that HHV increases significantly after the process. This is because of the increased fixed carbon content or carbon and hydrogen content. HHV of processed mixed component ranged from 29.944 to 37.313 $\mathrm{MJ} / \mathrm{kg}$ so that the hydrothermal process can increase HHV of the sample from 48.21 to 84.69. On the basis of the trend, HHV is higher for longer holding time operated, 90 minutes, while the influence of process water and process temperature is not clear in this result. However, the best condition of the hydrothermal process can be seen, which is the ratio of sample to water $1 / 1$, process temperature of $180^{\circ} \mathrm{C}$, and 90 minutes.

As discussed above, the process sample had high HHV, $37.313 \mathrm{MJ} / \mathrm{kg}$ which was higher than HHV of Indonesian coal $(30.03 \mathrm{MJ} / \mathrm{kg}$ ) [Muthuraman et al., 2010]. During the hydrothermal process, the carbon content was higher than the oxygen and hydrogen contents. Thus, both ratio

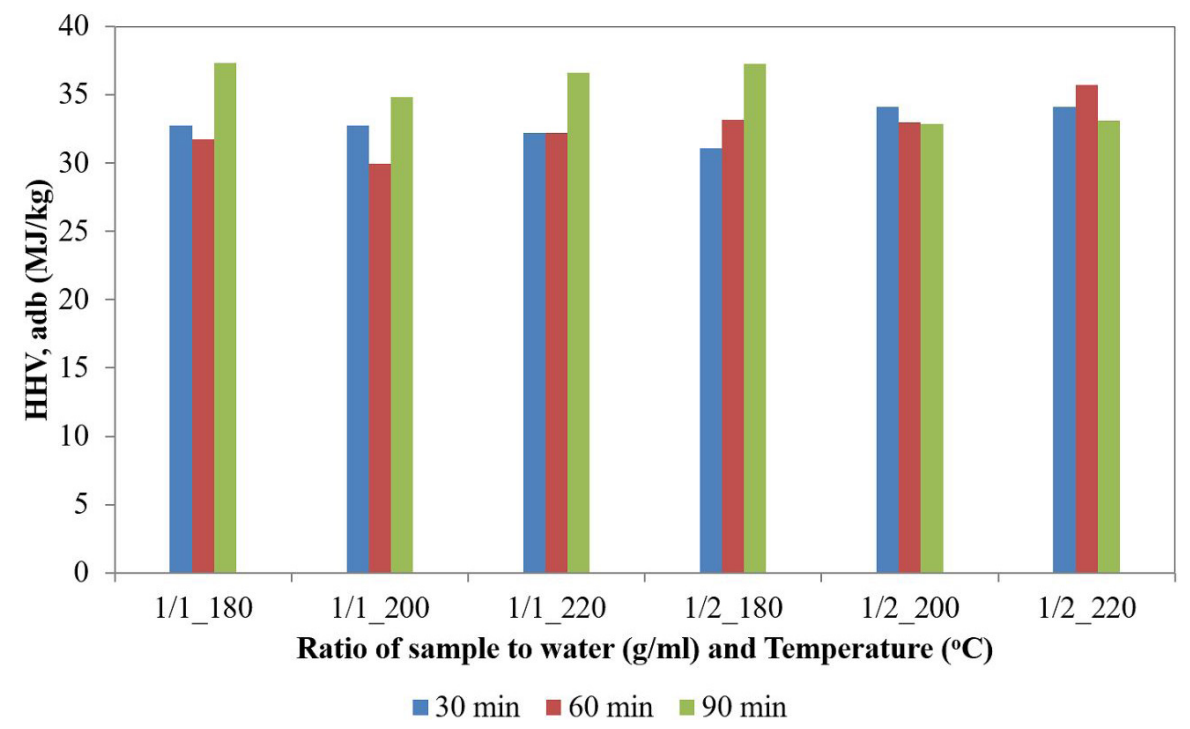

Figure 4. Variation of calorific value (HHV) of mixed component after hydrothermal process 


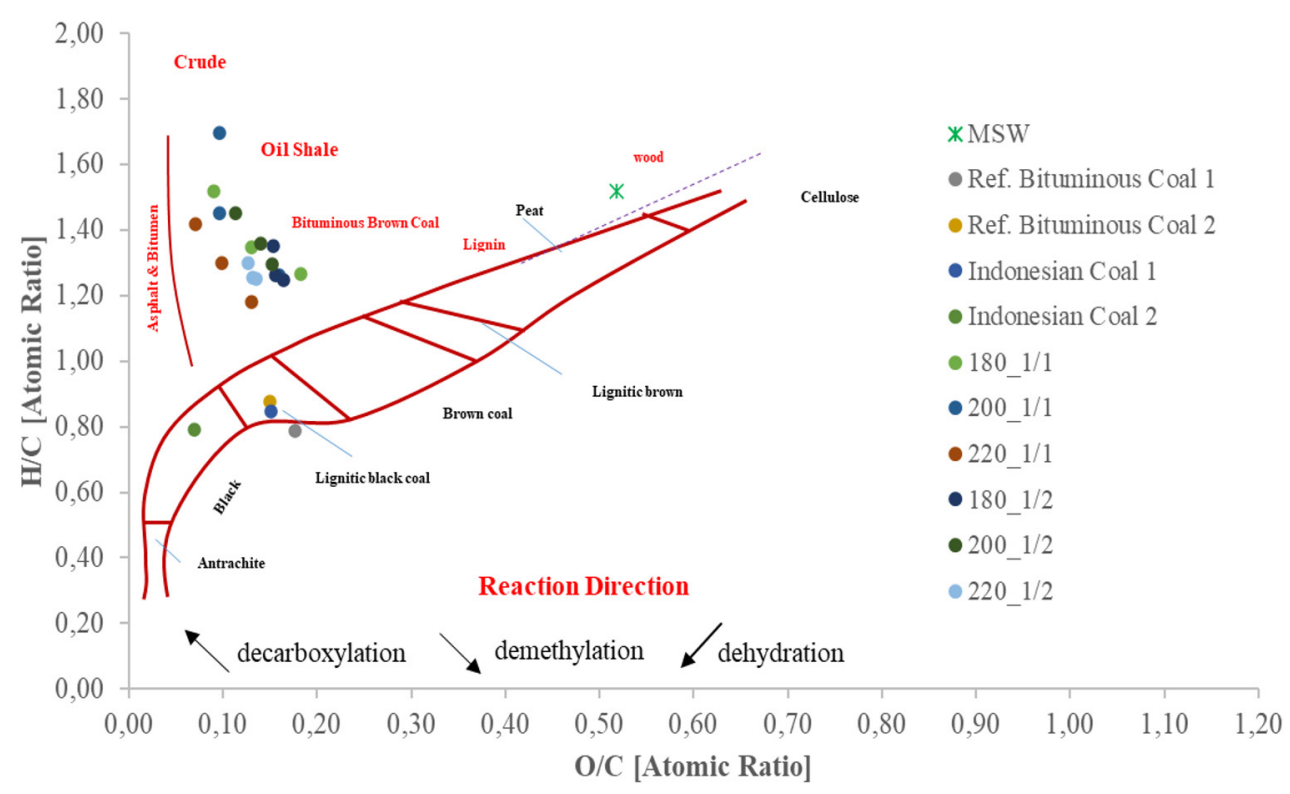

Figure 5. The van Krevelen Diagram

of $\mathrm{O} / \mathrm{C}$ and $\mathrm{H} / \mathrm{C}$ of the hydrochar were smaller compared to its feedstock. Figure 5 shows that the hydrochar had a smaller ratio of $\mathrm{O} / \mathrm{C}$ and $\mathrm{H} / \mathrm{C}$ and was close to coal zone. It also can be concluded that processed MSW can be burnt with coal in order to reduce coal consumption and the volume of MSW. This means that the hydrothermal treatment process is self-sustaining and can produce net solid fuel products.

\section{CONCLUSIONS}

The analyses (proximate, ultimate, and calorific value) of the processed samples proved that the process time, the water amount, and the temperature which were used in hydrothermal process affect the properties of sample. The process produced the samples with low moisture content and high VM which had high HHV. The highest HHV was $37.31 \mathrm{MJ} / \mathrm{kg}$ which was analyzed from the sample operated at a temperature of $180^{\circ} \mathrm{C}$, feed to water ratio $1 / 1$, and the holding time for $90 \mathrm{~min}$. It can be concluded that the hydrothermal process can be applied to MSW to produce solid fuel.

\section{Acknowledgement}

The authors would like to thank to Mr. Oman Rohman and the Research and Development Center of Mineral and Coal Technology (Tekmira) for the support of his research.

\section{REFERENCES}

1. BP Statistical Review of World Energy, Indonesia Insights. 2017. https://www.bp.com/content/ $\mathrm{dam} / \mathrm{bp} / \mathrm{en} /$ corporate/pdf/energy-conomics/statistical-review-2017/bp-statistical-review-of-worldenergy-2017-indonesia-insights.pdf (accessed on January 10, 2018)

2. Assmuth T. 1992. Distribution and attenuation of hazardous substances in uncontrolled solid waste landfills. Waste Management \& Research, 10(3), 235-255. DOI: 10.1016/0734-242X(92)90102-Q

3. Durmusoglu E., Taspinar F., Karademir A. 2010. Health risk assessment of BTEX emissions in the landfill environment. Journal of Hazardous Materials, 176(1-3), 870-877. DOI: 10.1016/j.jhazmat.2009.11.117

4. Funke A., Ziegler F. 2010. Hydrothermal Carbonization of Biomass: A Summary and Discussion of Chemical Mechanisms for Process Engineering. Biofuels Bioproducts \& Biorefining, 4, 160-177. DOI: $10.1002 / \mathrm{bbb} .198$

5. Goto M., Obuchi R., Hirose T., Sakaki T., Shibata M. 2004. Hydrothermal conversion of municipal organic waste into resources. Bioresource Technology, 93(3), 279-284. DOI: 10.1016/j.biortech.2003.11.017

6. He W., Li G., Kong L., Wang H., Xu J. 2008. Application of hydrothermal reaction in resource recovery of organic wastes. Resources, Conservation and Recycling, 52(5), 691-699. DOI: 10.1016/j. resconrec.2007.11.003

7. Hung M.L., Wu S.Y., Chen Y.C., Shih H.C., Yu Y.H., Ma H.W. 2009. The Health Risk Assessment of Pb and $\mathrm{Cr}$ leachated from fly ash monolith landfill. Journal of Hazardous Materials, 172(1), 316-323. DOI: 10.1016/j.jhazmat.2009.07.013 
8. Ji Y., Zhang S., Wang K., Qi G. 2020. Study on combustion and nitrogen oxide emissions of gas boiler. IOP Conf. Series: Materials Science and Engineering, 721, 012054. DOI: 10.1088/1757-899X/721/1/012054.

9. Jomaa S., Shanableh A., Khalil W., Trebilco B. 2003. Hydrothermal decomposition and oxidation of the organic component of municipal and industrial waste products. Advances in Environmental Research, 7(3), 674-653. DOI: 10.1016/S1093-0191(02)00042-4

10. Lander D., Fellner J., Brunner P.H. 2009. Flooding of municipal solid waste landfills - An environmental hazard? Science of the Total Environment, 407(12), 3674-3680. DOI: 10.1016/j.scitotenv.2009.03.006

11. Libra J.A., Ro K.S., Kammann C., Funke A., Berge N.D., Neubauer Y., Titirici M.M., Fühner C., Bens O., Kern J., Emmerich K.H. 2011. Hydrothermal carbonization of biomass residuals: a comparative review of the chemistry, processes and applications of wet and dry pyrolysis. Biofuels, 2(1), 89-124. DOI: $10.4155 / \mathrm{bfs} .10 .81$

12. Liang L., Sun R., Fei J, Wu S., Liu X., Dai K., Yao N. 2008. Experimental study on effects of moisture content on combustion characteristics of simulated municipal solid wastes in a fixed bed. Bioresource Technology, 99(15), 7238-7246. DOI: 10.1016/j. biortech.2007.12.061

13. Muthuraman M., Namioka T., dan Yoshikawa K. 2010. Characteristics of co-combustion and kinetic study on hydrothermally treated municipal solid waste with different rank coals: A thermogravimetric analysis, Applied Energy, 87, 141-148. DOI: 10.1016/j.apenergy.2009.08.004

14. Putra H.E., Damanhuri E., Dewi K., Pasek A.D. 2020. Production of coal-like solid fuel from albizia chinensis sawdust via wet torrefaction process. Journal of Ecological Engineering, 21(6), 183-190. DOI: $10.12911 / 22998993 / 123502$

15. Ramke H.G., Blöse D., Lehmann H.J., Fetting J. 2009. Hydrothermal carbonization of organic wastes. Twelfth International Waste Management and Landfill Symposium Proceedings. Sardinia, CISA Publisher. http://www.th-owl.de/fb8/fachgebiete/abfallwirtschaft/pdf/Sardinia_2009_HTC_Internet.pdf

16. Shanableh A. 2000. Production of useful organic matter from sludge using hydrothermal treatment. Water Research, 34(13), 945-951. DOI: 10.1016/ S0043-1354(99)00222-5 